\title{
ITS における複数情報の呈示方法に関する研究
}

\section{大門 樹（慶應義塾大学 理工学部）}

Study on Displaying Method for Multi-Information of Intelligent Transport Systems

Tatsuru DAIMON (Faculty of Science and Technology, Keio University)

\section{1.はじめに}

近年, AHS (走行支援道路システム)や ASV (先進安全自動車) などの ITS (高度道路交通 システム) の取り組み1にによって，ドライバー の安全性や利便性, 快適性の向上を目的とした 様々な情報提供が可能になる。しかしながら， これらの情報提供を従来の速度計や警告灯，ま た車載ナビゲーションシステムなどから構成 される連転環境に導入する際, それらの情報の 統合形式がドライバーにどのような影響を与 えるのかを十分に検討する必要がある. 本研究 では, 速度情報と経路誘導情報からなる運転環 境にITS の機能の1つである前方障害物情報 を付加した場合に, 呈示位置の組合せや聴覚信 号の併用によってドライバー行動がどのよう に影響されるかの初期的な検討を行った。

\section{2. 実験}

図1に示されるような実験装置を利用した。 150 インチスクリーンにはドライバーの前方 映像が投影され，ダッシュボード中央上と運転 席正面のインストルメントパネル内には, $2 つ$ の異なる情報を左右 2 分割で呈示できる液晶 ディスプレイが設置された. 実験条件に応じて 図 2 に示されるような速度情報, 経路誘導情報,

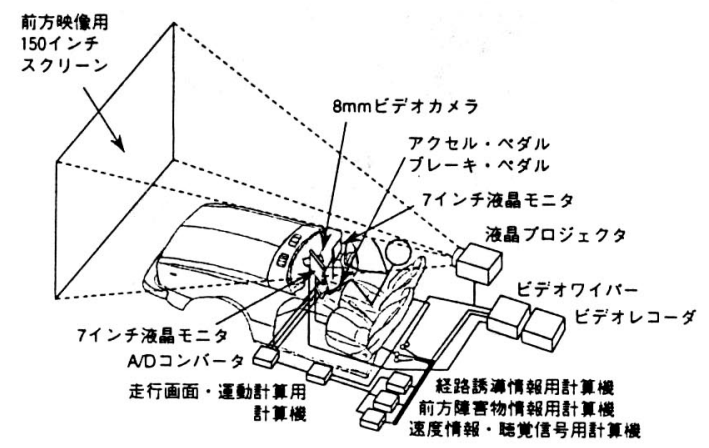

図 1 : 実験装置の概略図
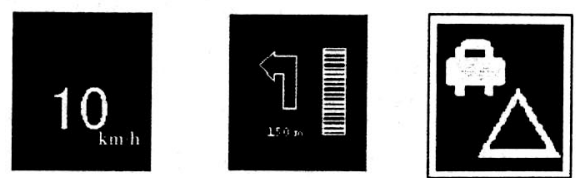

（a）速度情報 （b）経路誘導情報（c）前方障害物情報 図 2 : 呈示される情報内容

障害物情報が呈示された. 経路誘導情報および 障害物情報の呈示の際はそれぞれ聴覚信号が 付加された。 これらの情報は呈示位置の組合せ により, 表1のようなインタフェースを設定し

表 1 : 情報内容と呈示位置の組合せ

\begin{tabular}{|c|c|c|c|c|}
\hline & \multicolumn{2}{|c|}{ ダッシュボード上 } & \multicolumn{2}{|c|}{ 正面インパネ内 } \\
\hline & 左半分 & 右半分 & 左半分 & 右半分 \\
\hline インタフェース 1 & & 経路 & 速度 & 障害物 \\
\hline 侈フェース 2 & 障害物 & 経路 & 速度 & \\
\hline 㑕フェース & & 速度 & 経路 & 障害物 \\
\hline 价フIース4 & 障害物 & 速度 & 経路 & \\
\hline インタาIース 5 & & 障害物 & 速度 & 経路 \\
\hline インタフェース 6 & 経路 & 速度 & 障害物 & \\
\hline
\end{tabular}

た. 被験者には,これらのインタフェースを用 いて制限速度および経路誘導に従った運転操 作を行わせた。この実験装置での運転操作は， 通常の運転操作と同様にステアリング, アクセ ル・ブレーキを操作するが，速度制御および車 線保持制御に外乱が加えられているため, 適正 な状態を維持する調整操作を必要とした。また， 前方に障害物が存在する場合は実際の運転と 同様に衝突回避行動をとるよう指示した。障害 物は平均的な車両寸法で, 障害物の手前 $100 \mathrm{~m}$ で被験者の視界に現れるように設定した。被験 者には「経路選択を間違えないこと」「できる 限り制限速度で走行すること」「障害物がある 場合には回避行動をとること」を指示した．被 験者は 21 歳から 22 歳の健康な学生 5 名（男 性 3 名, 女性 2 名）で, 運転経験は 1 年以上あ り，運転能力に関して問題はなかった。 


\section{3. 結果および検討}

今回の実験では, 経路選択ミスや障害物回避 ミスは見られず, 速度制御および車線保持制御 についてもインタフェースによる大きな違い は見られなかったことから, 運転作業に関して 一定の水準が維持されていたと考えられる。一 方, 注視行動や主観評価に関してインタフェー スによる違いが若干見られた。図 3 に注視行動 の結果を示す.頻繁に注視すると考えられる速

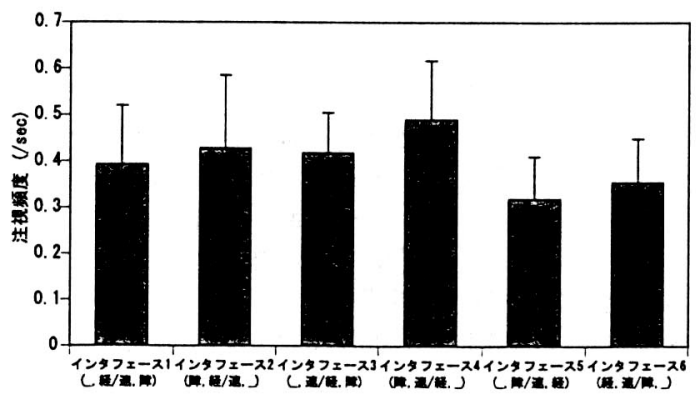

(a) 平均注視頻度

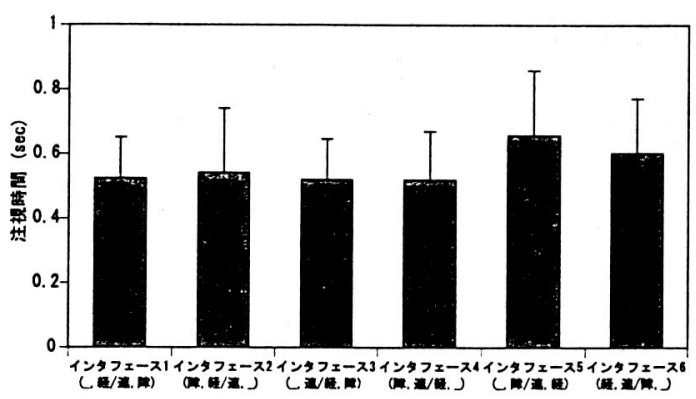

(b) 平均注視時間

図 3 : 呈示情報に対する注視行動

度情報と経路誘導情報が異なる呈示領域にあ る場合には，注視頻度が高く，注視時間が短く なる特徵が見られたが，逆に同じ呈示領域にあ る場合には，注視頻度が低く，注視時間が長く なるといった特徵が見られた。同じ領域に速度 情報と経路誘導情報が呈示されている場合に

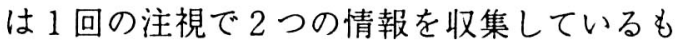
のと考えられる。

ドライバーが前方障害物情報を認知した際 の状況分類を図 4 に示す. どのインタフェース においても前方障害物情報の認知の $50 \%$ 以上 が聴覚信号の呈示により気づいたものであり， 周辺視による認知は割合として少なかった. 前 方に障害物が存在する状況は突発事象と考え られることから, 速度情報や経路誘導情報とは

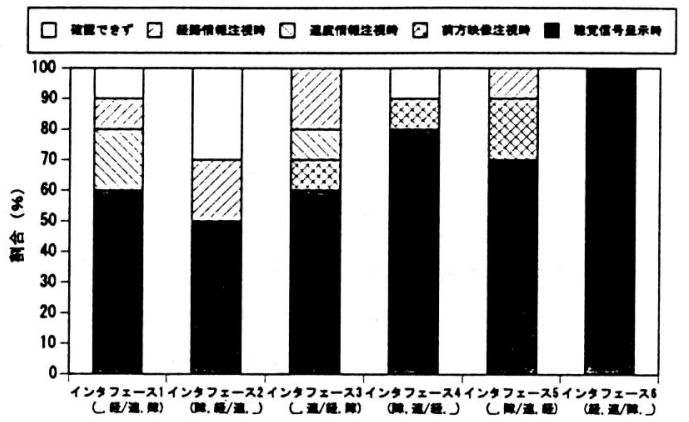

図 4：障害物情報の認知

異なり，視覚による能動的な情報収集が行われ にくいものと考えられる。

各インタフェースに対する「使いやすさ」の 主観的評価の結果を図 5 に示す. 速度情報と経

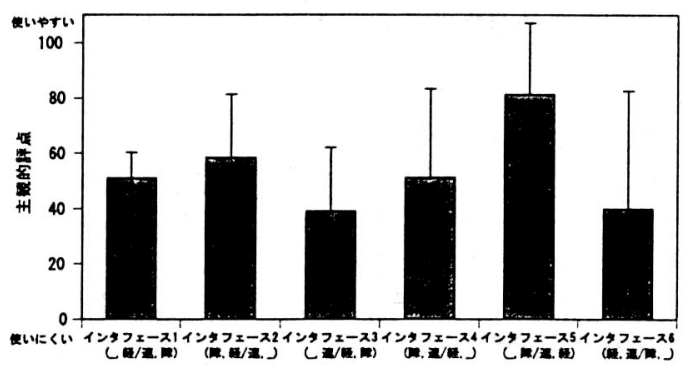

図 5 :「使いやすさ」に関する主観的評価

路誘導情報を正面インストルメントパネル内 に，障害物情報をダッシュボード上に呈示した インタフェース 5 が高い評価を受けたが, 逆に インタフェース 3 やインタフェース 6 は中間 評点よりも若干「使いにくい」寄りの低い評価 を受けた.インタフェース 5 とインタフェース 6 では, 速度情報と経路誘導情報を同じ領域に 呈示しているにもかかわらず，「使いやすさ」 に関して異なる評価がなされた. 実験終了後の 被験者へのインタビューにおいて, 速度制御を 行うには速度情報を頻繁に注視する必要があ ったとの回答が得られていることから, 速度情 報と経路誘導情報の利用頻度などをさらに詳 細に検討する必要がある. 前方障害物情報につ いては，聴覚信号による効果が大きかったが， 危険回避という点では他の情報より優先度が 高く, 情報の優先度と情報の呈示方法について の検討が必要であると考えられる。

\section{参考文献}

1）野口好一：ITS（高度道路交通システム）, 自動車技術，53(8)，173·177，1999 